\title{
EDITORIAL
}

\section{AMPLIAÇÃO DE CAMINHOS}

Comente este artigo no blog Ebibli = $\underline{\text { http://encontros-bibli-blog.blogspot.com/ }}$

Completados dez anos de exposição pública, parece inevitável que Encontros Bibli deva, por sua equipe, olhar muito mais para a frente. Sua trajetória, que partiu de uma edição inicial composta por um único e solitário artigo, teve na edição 22 doze artigos publicados. Claro que entre os dois momentos aconteceu a idéia da implantação de um projeto possível e a caminhada que, não apenas deu contornos a esse projeto possível como hoje o apresenta já na condição de uma realidade institucional. Atualmente, Encontros Bibli insere-se no conjunto das publicações periódicas brasileiras do campo da Ciência da Informação, que se abre ao mundo, que recepciona e publiciza a produção oriunda da elaboração de pesquisadores atuantes em outros países e, ao mesmo tempo, através de suas edições especiais, tenta trazer as reflexões em torno de temas novos ou com um diferencial de abordagem na Ciência da Informação.

Essa ampliação, que entendemos seja um alargamento de caminhos, equivale ao esforço dos exploradores que, nas densas florestas, fazem o caminho ao pôr-se a caminho. Isso faz de Encontros Bibli um lugar onde pesquisadores da Ciência da Informação nos reunimos para caminhar e fazer caminhos: caminhos de conteúdos, caminhos de expressão desses conteúdos que, como tais, representam as estradas principais e as estradas vicinais, que como caudatárias das estradas principais complementam a estas. No nosso caso, nossa estrada principal são as edições que chamamos de regulares; nossas estradas vicinais, não de menor importância, são as edições especiais temáticas ou institucionais e, mais recentemente, o nosso blog [http://encontros-bibli-blog.blogspot.com/] criado com o propósito de tornar disponível um espaço em que os leitores de Encontros Bibli possam avaliar e emitir opinião sobre as matérias publicadas pelo periódico.

Mantendo essa expectativa de ampliação de caminhos, Encontros Bibli oferece aos seus leitores esta edição especial temática sobre SEMIÓTICA E INFORMAÇÃO, competentemente organizada pela Professora Célia Regina Simonetti Barbalho, Doutora em Comunicação e Semiótica e atuante no quadro docente da Universidade Federal do Amazonas.

O fascículo que ora se abre à leitura compõe-se de seis artigos em que os autores fazem um esforço de evidenciação das relações entre os dois campos do conhecimento enunciados no título desta edição, isto é, a Semiótica e a Ciência da Informação.

Como sempre, esperamos que este esforço que envolveu a organizadora do fascículo, os autores, os avaliadores, a Comissão Editorial de Encontros Bibli passe, a partir do seu lançamento, a envolver os leitores e todos os demais interessados de maneira tal que possam 
opinar em nosso blog, possam tomar essa produção como parte de seus estudos, dando a Encontros Bibli o retorno que todos os envolvidos na publicação de periódicos científicos desejam que é o da citação, isto é, do reconhecimento de qualidade dos conteúdos publicados: méritos dos autores, é certo, mas também merecimento de quantos se envolveram para dar vida à ciência que só o é quando é tornada pública. Com isso, a ampliação de caminhos se torna mais viva, pois, acolhe mais caminhantes, todos com o fim de melhor entender a densa floresta que é o conhecimento humano.

Dito isto, desejamos a todos/as uma boa leitura!

Prof. Francisco das Chagas de Souza

Editor

Departamento de Ciência da Informação

Programa de Pós-Graduação em Ciência da Informação

Universidade Federal de Santa Catarina

Brasil

Florianópolis, SC, Brasil

Novembro de 2006 